\title{
DEVELOPING THE SKILL OF TAKING NOTES FOR ENGLISH MAJORS THROUGH LISTENING TO ENGLISH NEWS
}

\author{
Nguyen Danh Nam, Tran Thi Yen*, Tran Nhat Le \\ $T N U$ - University of Education
}

\begin{abstract}
Note-taking skill plays an important role when listening to English. The aim of this study is to investigate the impact of listening to English news on the skill of taking notes of English majors at Thai Nguyen University of Education. 20 students were chosen randomly, 10 of them were put in the experimental group and the others in the control group. The experimental group was introduced some methods of taking notes while listening to English news. The researcher asked them to listen to English news every day and use these methods to take notes. The data of the study were analyzed and compared between the two groups. The findings of this study indicate that the experimental group is better than the control group in both note-taking skill and listening test scores. This demonstrates that listening to English news has a significant positive impact on English majors' note-taking skill and listening performance. After the experiment, a questionnaire was delivered to the experimental group to collect students' feedback on the new method.
\end{abstract}

Keywords: listening; note taking skill; note taking strategies; listening performance; English news.

Received: 04/02/2020; Revised: 28/02/2020; Published: 17/3/2020

\section{PHÁT TRIỂN KỸ NĂNG GHI CHÚ CHO SINH VIÊN CHUYÊN NGÀNH TIẾNG ANH THÔNG QUA NGHE TIN TỨC TIẾNG ANH}

\author{
Nguyễn Danh Nam, Trần Thị Yến*, Trần Nhật Lệ \\ Truòng Đại học Su phạm - ĐH Thái Nguyên
}

\section{TÓM TẮT}

Kỹ năng ghi chú đóng vai trò quan trọng khi nghe tiếng Anh. Mục đích của nghiên cứu này là khảo sát tác động của việc nghe tin tức tiếng Anh lên kỹ năng ghi chú của sinh viên chuyên ngành tiếng Anh tại Trường Đại học Sư phạm - Đại học Thái Nguyên. 20 sinh viên được chọn ngẫu nhiên, 10 trong số đó được đưa vào nhóm thực nghiệm và 10 sinh viên còn lại nằm trong nhóm đối chứng. Nhóm thực nghiệm được giới thiệu một số phương pháp ghi chú trong khi nghe tin tức tiếng Anh và được yêu cầu nghe tin tức tiếng Anh mỗi ngày đồng thời sử dụng các phương pháp ghi chú. Kết quả nghiên cứu được phân tích và so sánh giữa hai nhóm chỉ ra rằng nhóm thực nghiệm tốt hơn nhóm đối chứng ở cả kỹ năng ghi chú và điểm kiểm tra nghe. Điều này chứng tỏ việc nghe tin tức bằng tiếng Anh có tác động tích cực đáng kể đến kỹ năng ghi chú của sinh viên chuyên ngành tiếng Anh cũng như khả năng nghe của họ. Sau thực nghiệm, một bảng câu hỏi đã được tiến hành trên nhóm thực nghiệm để thu thập phản hồi của sinh viên về phương pháp mới.

Từ khóa: nghe; kỹ năng ghi chú; chiến luợc ghi chú; khả năng nghe; tin tức tiếng Anh

Ngày nhận bài: 04/02/2020; Ngày hoàn thiện: 28/02/2020; Ngày đăng: 17/3/2020

\footnotetext{
* Corresponding author. Email: yentran@dhsptn.edu.vn
} DOI: https://doi.org/10.34238/tnu-jst.2020.03.2589 


\section{Introduction}

Learning foreign languages has become a matter of concern in today's society. When accessing a new language, many students have difficulty in practicing the most basic skill of a language: listening skills. One of the most indispensable sub-skill of listening that helps learners listen well is the note-taking sub-skill.

Pialot [1] defines note-taking as a collection of information retrieved from single or multiple sources to retain memory and to help us carry out events and activities. Castallo [2] has defined note-taking as a two-step process in which students must listen for the important information and then write it in some organized way. Fajardo [3] has indicated that "note-taking is the combination of different skills like reading or listening, selecting, summarizing and writing", and it is also a requirement of selecting the related information from the unnecessity. According to Cary and Calson [4], notes are similar to a rough draft in that they allow information to be coded, thus relieving mnemonic processes and consequently helping with the development of the solution.

Note-taking is also very important in the study process and is a key factor to become a successful learner. For listening skills, note taking is an effective tool to memorize the information that you hear. Even if learners have a great memory, they simply won't be able to remember all the information. Besides, more attention and better listening facilities are showed through taking notes. While learners take notes, they are required to be listening very well to whoever is providing the information, and they are also supposed to pay a lot of concentration. So, in order to take good notes, they are forced to pay attention and listen closely to what is being talked. This would help to develop their listening abilities.

However, learning this subskill presents a series of challenges. Some learners do not consider taking notes an important skill, so they do not actively practice the skill. Moreover, they may not find appropriate methods for themselves. Therefore, understanding the importance of listening subskill of note-taking and the difficulties in practicing the note-taking process, we conduct the study "Developing the skill of taking notes for English majors through listening to English news" with the hope that English majors in general and English majors at Thai Nguyen University of Education (TUE) in particular can improve their listening sub-skill of note-taking, thence helping them improve their listening performance and be more confident when communicating with foreigners.

\section{Aims of the study}

The study aims at, firstly, investigating the current situation of taking notes while listening to English by English majors at TUE, secondly, improving their skill of taking notes through listening to English news, and finally, investigating the relationship between the quality of notes taken by students and their listening performance.

The study has three major research questions as follows:

i. What is the current situation of taking notes while listening among English majors at TUE?

ii. To what extent does listening to English news have impacts on English major's listening sub-skill of note-taking?

iii. What is the relationship between the quality of notes taken by students and their listening performance?

\section{Methodology}

\subsection{Research methods}

The research has been done based on mixed methods because it combined experimental method and quantitative method. First -of all, an experiment was conducted to examine the impacts of listening to English news on the 
skill of taking notes for English majors at TUE. Along with the experimental method, the quantitative method was undertaken with questionnaires to collect data and learner's feedback on using English news to improve their listening sub-skill of note taking after having finished the experiment.

\subsection{The participants}

Twenty first-year English majors at TUE were asked to take part in the research. The researcher put 10 students into the experimental class (the experimental group) and 10 in the traditional class (the control group), and only the experimental class experienced the new method.

\subsection{Data collection instruments}

\subsubsection{Pre-questionnaire}

The researcher constructed the prequestionnaire with 11 questions for both the experimental group and the control group to collect information about the current situation of using note-taking skill while listening to English of TUE English majors; especially, their attitudes and opinions about note-taking skill and their difficulties as well as methods when practicing the skill of taking notes.

\subsubsection{Pre-test}

The pre-test was aimed to discover students' note taking skill before experiencing the new method. The test was based on the format of PET listening test, in which there were 4 parts with 25 questions. Both the experimental and the control groups took the pre-test. After that, the researcher collected and analyzed the students' notes as well as marked their paper. Based on the results of the pre-test, the researcher placed the chosen students into 2 groups on a condition that both groups' level of English proficiency was similar. The experimental group improved their notetaking skill by listening to English news while the control group did not.

\subsubsection{Post-test}

The researcher asked the two groups to take the post-test, which was also based on the format of the PET listening test. Next, the researcher collected and analyzed the students' notes, and then compared them with the results of the post-test to find out whether or not there is a relationship between good notes and listening performance. The researcher also compared the results of the pre-test with those of the post-test as well as the test results of the experimental group with those of the control group in order to assess the difference between before and after implementing the new method.

\subsubsection{Post questionnaire}

Seven questions were designed for the postquestionnaire. The questionnaire was used to collect data regarding students' listening level, their attitude about listening to English news to improve their note taking skill and their suggestion to improve the effectiveness of using English news to enhance the skill. The researcher constructed the postquestionnaires for the experimental group. The questionnaire was posted on the facebook group of students who took part in the experiment. The researcher asked them to answer the questionnaire with their exact information. The researcher compared the results of the post-questionnaire with those of pre-questionnaire to know how students' attitudes and opinions changed after taking part in the research.

\section{Results and discussion}

\subsection{The current situation of taking notes while listening among English majors at TUE}

4.1.1. The frequency of employing notetaking skill while listening to English

In the pre-questionnaire, the researcher asked students about their frequency of using notetaking skill while listening to English. According to the survey, $65 \%$ of the students said that they usually take notes while 
listening to English news and the others indicated that they do not often use notetaking skill in the listening process.

\subsubsection{Main difficulties when taking notes}

The researcher also gathered students' opinions about their problems when taking notes. The results, which are summarized in Table 1, indicated that the biggest difficulty when taking notes is that they do not have enough time to copy and take notes and can not hear all the information to take notes in the listening process. Lack of vocabulary was the second difficulty which half of the students face while listening to English. Two students claimed that they can not summarize the ideas when they listen to English.

Table 1. Main difficulties when taking notes

\begin{tabular}{|c|c|c|}
\hline Difficulties & No. & $\%$ \\
\hline $\begin{array}{l}\text { I do not have enough time to copy } \\
\text { and take notes }\end{array}$ & 11 & 55 \\
\hline I can not summarize the ideas & 2 & 10 \\
\hline $\begin{array}{l}\text { I can not hear all the information } \\
\text { to take notes }\end{array}$ & 11 & 55 \\
\hline I lack vocabulary & 10 & 50 \\
\hline
\end{tabular}

\subsubsection{Difficulties in practicing note-taking skill}

The researcher asked students to give their opinions about their difficulties when practicing the skill of taking notes. Table 2 reveals these difficulties.

Table 2. Difficulties in practicing note-taking skill

\begin{tabular}{lcc}
\hline \multicolumn{1}{c}{ Difficulties } & No. & \% \\
\hline I don't have enough time to practice & 10 & 50 \\
$\begin{array}{l}\text { I don't have any suitable method to } \\
\text { practice }\end{array}$ & 17 & 85 \\
$\begin{array}{l}\text { I don't think it is an important skill } \\
\text { to practice }\end{array}$ & 0 & 0 \\
\hline
\end{tabular}

As can be seen from the table, the biggest difficulty is that students could not find a suitable method to practice the skill. Half of the participants indicated that they do not have enough time to practice the skill of taking notes. No one thought that note- taking is not an important skill for them to practice.
From this analysis, it is obvious that students considered note-taking skill important for them when listening but they lack appropriate method to practice the skill; therefore, it is necessary to provide an interesting and useful method to help students overcome their difficulties.

\subsubsection{The items that students often take notes of while listening to English}

Table 3 reveals the items which are often written down by students.

Table 3. Main items students often take on their notes while listening to English

\begin{tabular}{lcc}
\hline \multicolumn{1}{c}{ Items } & No. & \% \\
\hline Keywords & 14 & 70 \\
Main ideas & 8 & 40 \\
Every thing I can hear & 9 & 45 \\
Spellings & 1 & 5 \\
Probable answers & 3 & 15 \\
\hline
\end{tabular}

As can be seen from the table, most of the students indicated that key words are the items they often take notes of while listening to English. Main ideas and every information that students can hear will be taken on the notes of more than $40 \%$ of the students. $15 \%$ of the participants answered that they often note probable answers in their listening process. Only one student revealed that spellings could be noted down while he/she listens to English.

\subsubsection{Methods that students use to take notes}

Table 4. Methods students use to take notes

\begin{tabular}{lcc}
\hline \multicolumn{1}{c}{ Methods } & No. & \% \\
\hline Write main points only & 10 & 50 \\
Try to write down every word & 8 & 40 \\
$\begin{array}{l}\text { Translate to Vietnamese to write } \\
\text { down }\end{array}$ & 1 & 5 \\
Use symbols and abbreviation & 6 & 30 \\
\hline
\end{tabular}

Table 4 presents the students' common methods of taking notes. It can be seen that half of the students often write down the main points only on their notes in the listening process. $40 \%$ of the students try to write down every word that they can hear while 
listening to English. 6 participants said that they use symbols and abbreviations to write down the information when taking notes.

4.1.6. The use of English news to improve notetaking skill

The researcher also asked students about the frequency of using English news to practice their note-taking skill. The results show that more than half of the students (55\%) have not used English news to improve their notetaking skill while $45 \%$ said yes.

\subsection{Impacts of listening to English news on students' note-taking skill}

The following quantitative measures (see Table 5) and qualitative measures (see Table 6 ) were adopted from the measures developed by Song [5] to serve as a suitable calculation tool for evaluating notes.

Table 5. Quantitative measures

Information:
1. $\quad$ Main ideas
2. $\quad$ Supporting ideas
3.

Strategies:

4. Abbreviations

5. Symbols

Song claimed that good notes have clear information with hierarchical delineation that shows different levels of information: main, supporting ideas and minor details.
The students' notes can also be evaluated based on a scoring rubric below; each participant's notes were scored from 0-3.

Table 6. Qualitative measures

\begin{tabular}{|c|c|c|}
\hline & Structure & Criteria \\
\hline $\begin{array}{c}\text { Well } \\
\text { organized } \\
\text { (score: } 3 \text { ) }\end{array}$ & $\begin{array}{c}\text { Clear } \\
\text { hierarchical } \\
\text { structure }\end{array}$ & $\begin{array}{l}\text { Most main and } \\
\text { supporting ideas are } \\
\text { recorded in an } \\
\text { organized way (e.g. } \\
\text { topics, sub-topics, } \\
\text { numbering...). } \\
\text { Notes show the } \\
\text { relationships among } \\
\text { words and concepts }\end{array}$ \\
\hline $\begin{array}{l}\text { Partially } \\
\text { organized } \\
\text { (score: } 2)\end{array}$ & $\begin{array}{c}\text { Some } \\
\text { hierarchical } \\
\text { structure }\end{array}$ & $\begin{array}{l}\text { Some main and } \\
\text { supporting ideas are } \\
\text { recorded in an } \\
\text { organized way }\end{array}$ \\
\hline $\begin{array}{c}\text { Poorly } \\
\text { organized } \\
\text { (score: } 1)\end{array}$ & $\begin{array}{c}\text { Only a } \\
\text { little }\end{array}$ & $\begin{array}{l}\text { Only a few main } \\
\text { and } \\
\text { ideas are recorded. }\end{array}$ \\
\hline $\begin{array}{c}\text { Not } \\
\text { organized } \\
(\text { score: } 0)\end{array}$ & None & $\begin{array}{l}\text { Only a little } \\
\text { information } \\
\text { without organization. }\end{array}$ \\
\hline
\end{tabular}

4.2.1. The quantity of the experimental group's notes in the pre-test

To assess the impacts of using English news on students' note-taking skill, the researcher analyzed the quantity and quality of notes in the pre-test and post-test to see the differences of their notes after the experiment.

Table 7 presents the quantity of notes of the experimental group in the pre-test. In the table, names of students are coded as $\mathrm{C}+$ number which means Control or E+number which means Experimental.

Table 7. The quantity of the experimental group's notes in the pre-test

\begin{tabular}{ccccccc}
\hline \multirow{2}{*}{ Participants } & \multicolumn{3}{c}{ Information } & \multicolumn{2}{c}{ Strategies } & \multirow{2}{*}{ Total } \\
words
\end{tabular}


It is clear that all of the students could not take down the main ideas and supporting ideas. The information that most of the students could take down was the details. However, the number of details that they took is very poor, mainly simple details. Some of them even did not take any notes while listening. None of the participants used strategies as symbols and abbreviations to take their notes.

\subsubsection{The quantity of the experimental group's notes in the post-test}

The researcher analyzed the quantity of students' notes in the post-test to exploit the changes in students'notes after experiencing the new method. The results are presented in Table 8.

Table 8. The quantity of the experimental group's notes in the post-test

\begin{tabular}{ccccccc}
\hline \multirow{2}{*}{ Participants } & \multicolumn{3}{c}{ Information } & \multicolumn{2}{c}{ Strategies } & Total \\
\cline { 2 - 5 } & Main ideas & Supporting ideas & Details & Abbreviations & Symbols & words \\
\hline E1 & 0 & 1 & 15 & 1 & 2 & 19 \\
E2 & 0 & 2 & 21 & 0 & 1 & 24 \\
E3 & 0 & 0 & 14 & 0 & 2 & 16 \\
E4 & 0 & 1 & 17 & 0 & 1 & 19 \\
E5 & 1 & 2 & 15 & 2 & 2 & 22 \\
E6 & 1 & 1 & 38 & 2 & 3 & 45 \\
E7 & 0 & 0 & 13 & 0 & 2 & 15 \\
E8 & 0 & 0 & 14 & 0 & 0 & 14 \\
E9 & 2 & 3 & 32 & 3 & 2 & 42 \\
E10 & 0 & 0 & 12 & 0 & 0 & 12 \\
\hline
\end{tabular}

From the table, it is clear that most of the participants could not take notes of the main ideas and supporting ideas when they listened. However, there were 3 participants who could write down some main ideas and half of them could take some supporting ideas. In the post-test, most of the students could take a large number of details. The number of students who could use abbreviations to take down their notes was 4 students. Most of the participants could use 1 to 3 common symbols to take notes.

In sum, although the improvements in the quantity of the experimental group's notes were not too impressive, there was a clear change in the number of notes taken by the students in the experimental group.

\subsubsection{The quality of the students' notes in the pre-test}

Based on the qualitative measures of Song [5], the researcher evaluated the score of the quality of students' notes as shown in table 9.

Table 9. The scores of the quality of notes taken by students

\begin{tabular}{ccccc}
\hline \multirow{2}{*}{ Participants } & \multicolumn{2}{c}{ Pre-test } & \multicolumn{2}{c}{ Post-test } \\
\cline { 2 - 5 } & E+ & C+ & E+ & C+ \\
\hline 1 & 0 & 0 & 0 & 0 \\
2 & 0 & 0 & 1 & 0 \\
3 & 0 & 0 & 0 & 0 \\
4 & 0 & 0 & 0 & 0 \\
5 & 0 & 0 & 1 & 0 \\
6 & 0 & 0 & 1 & 0 \\
7 & 0 & 0 & 0 & 0 \\
8 & 0 & 0 & 0 & 0 \\
9 & 0 & 0 & 2 & 0 \\
10 & 0 & 0 & 0 & 0 \\
\hline
\end{tabular}

From table 9, it is clear that the quality of notes taken by the students of the two groups in the pre-test was very poor. They just noted only a little information without organization; therefore, their scores of quality of notes were both 0 .

In the post-test, the quality of the experimental group's notes was improved. 
There were 3 participants in the experimental group who got 1 point and one got 2 points. In contrast, all of the students in the control group could not get any point for their notes.

To summarize, the quality of some members of the experimental group's notes is improved while the quality of the control group's notes is not. However, most of these notes improved unremarkably. There were only a few main and supporting ideas which were recorded. The students who got high score in the quality of notes are those who could take down main ideas and supporting ideas in their notes. These results suggest that good structure, containing more main ideas and supporting ideas are indicators of good quality notes. Although the quality of notes that the experimental group took are not too impressive, some of them can improve their notes and know how to organize their note efficiently. This means that students can improve their note-taking skill through listening to English news after the experiment.

4.2.4. The listening test scores of the experimental and control group

Figure 1 shows the average listening test scores of the participants.

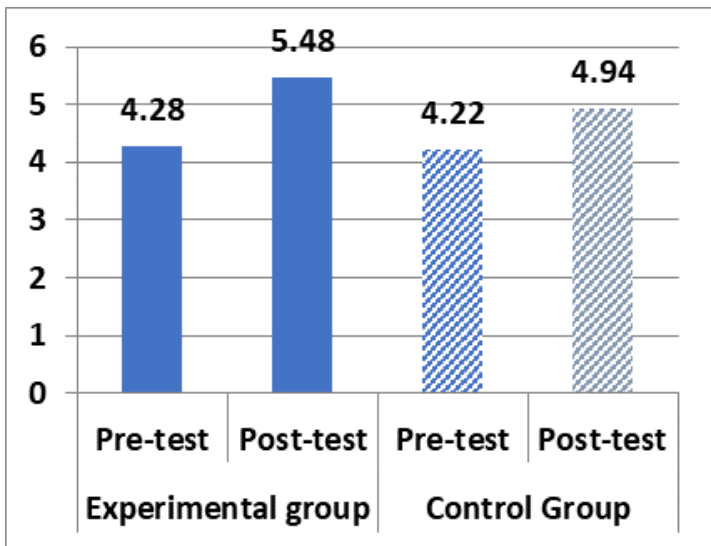

Figure 1. Listening test scores of the experimental and control group

It can be seen that both the experimental group and control group have made significant progress during the semester since there are noticeable differences between the pre-test and post-test scores. Specifically,

- The average pre-test score of the experimental and traditional group is $4.28 / 10$ and 4.22/10, respectively. In other words, both groups' level of listening performance is almost similar.

- The average score of the experimental group in the post-test is 5.48; however, the average score of the traditional group is only 4.94 although both groups' level of listening performance before the experiment is quite similar.

To sum up, there a big difference between pre-test scores and post-test scores of the participants in the experimental group while there is an unremarkable gap between pre-test scores and post-test scores of 10 students in the control group. It is visible that along with the development of students' note-taking skill, participants' listening performance is also improved when listening to English news and taking notes at the same time. Besides, from the evaluation about the quality of notes taken by students, the researcher found that the students who have better notes got higher scores in their listening test. In the control group, the improvement in the quality of notes and listening performance seems to be insignificant. This demonstrates that good notes help students get better results in their listening performance.

4.3. Students' feedback on using English news to improve note-taking skill

In the post-questionnaire, the researcher asked the participants in the experimental group for their feedback on using English news to improve their note-taking skill. All of the students indicated that they find their notetaking skill improved. None of the participants claimed that their skill of taking notes has no development. This means that listening to English news has a positive effect on students' note-taking skill. 
Regarding the advantages of English news, $70 \%$ of the participants stated that English news is fun and useful for them to practice note-talking skill. Half of the students said that it not only helps learners improve notetaking skill but also helps them know more about what is happening in everyday life. The next advantage of listening to English news stated by $30 \%$ of the students is that it helps them get accustomed to the speed of speakers in the listening tasks. Six participants answered that listening to English news helps them relax as well as practice their notetaking skill instead of spending their free time for other unnecessary activities.

5. Recommendation for students in practicing the skill of taking notes

\subsection{Use symbols and abbreviations}

A system of note-taking abbreviations, symbols and acronym has to be gradually formed. Using acknowledged symbols or creating own symbols to stand for longer information saves time and makes it much easier to grasp information and do better listening.

\subsection{Write phrases or ideas, not full sentences}

Don't take down every thing which is said in the notes. Effective listening note-taking involves identifying the overall argument and note the main points and key information. Only write down the key words that are necessary to get the idea of the information. Skip some words like article "a/an/the" that do not add additional meaning to the content. Retain key technical or specific terms.

\subsection{Take notes using the student's own words}

Paraphrase what is heard in order to makes sense - it helps learners understand and remember what they hear. Try to paraphrase everything except the information that needs to be noted exactly such as probable names.

\subsection{Organize the notes like a bibliography}

Use titles to indicate topic areas or to include bibliographical details of the sources of information. Use outline form with a numbering system and indenting to help distinguish major from minor points.

\subsection{Leave a space on notes for your own notes and comments.}

If students miss something, they should write key words, skip a few spaces, and get that information later.

\subsection{Concentrate and pay attention}

Be prepared to actively listen and learn, and to think criticially. Analysing and questioning the information helps learners focus and understand what they listen.

5.8. There are various sources of English news for students to listen. However, not all the sources suitable for their level. That is why they should choose a suitable source of English news to listen.

Some common sources of English news are VOA News, VOA Idiom Dictionary, VOA Wordbook, BBC News, and CNN News.

\section{Conclusion}

The results of the study can be summerized as follows:

Firstly, regarding the first research question, it is visible that note-taking is a common skill for most of the participants while they listen to English. Moreover, students encountered some difficulties when using as well as practicing the skill and the biggest problem they have to face is that they can not find a suitable method for practicing this skill. Therefore, it is necessary for students to discover a useful method to help them overcome the problem. Besides, not many students listen to English news to improve their note-taking skill. In other words, improving the skill of taking notes by listening to English news is a new method for many English majors. 
As for the second research question, it is clear that at first the experimental group's notetaking skill was as poor as the control group's. However, after the experiment, the quantity and quality of notes of the experimental group were much higher than the control group. The details that the experimental group could write down were phrases or sentences while the control group just wrote down some simple words. The experimental group could also use some strategies to take down their notes while the control group could not. The quality of some of the experimental group's notes is also improved while that of the control group is not. Although the quality of notes that the experimental group took is not too impressive, some of them can improve their notes and know how to organize their notes efficiently. This means that students can improve their note-taking skill through listening to English news.

Next, it is undeniable that taking good notes has a positive effect on students' listening performance. This is to say, along with the development of students' note-taking skill, their listening performance is also improved significantly and it made a big difference between pre-test scores and post-test scores of the participants. Besides, from the evaluation about the quantity and quality of notes taken by students, the researcher found that the students who have better notes got higher scores in their listening test. For the control group, with notes poor in quantity and quality, their test scores improved insignificantly. This demonstrates that good notes have positive impacts on students' listening performance.

Finally, by analysing the questionnaire responses gathered, the researcher realizes that the new method encourages student's interest and desire to improve note-taking skill. In other words, they will still keep a positive attitude and continue to use the new method as a helpful tool to develop their skill of taking notes.

\section{REFERENCES}

[1]. A. Piolat, T. Olive and R. T. Kellogg, "Cognitive effort during note taking," Applied Cognitive Psychology, vol.19(3), pp. 291-312, 2005.

[2]. R. Castallo, "Listening guide - A first step toward note-taking and listening skills," Journal of Reading, vol. 19(4), pp. 289-290, 1976.

[3]. C. P. Fajardo, "Note-taking: A useful device," English Teaching Forum, vol. 34(2), pp. 2226, 1996.

[4]. M. Cary and R. A. Carlson, "External support and the development of problem-solving routines," Journal of Experimental Psychology: Learning, Memory, and Cognition, vol. 25(4), pp. 1053-1070, 1999.

[5]. M. Y. Song, "Note-taking quality and performance on an L2 academic listening test," Language Testing, vol. 29(1), pp. 67-89, 2012. 